\title{
A Case of High Dose Metoprolol Poisoning; Case Report and Literature Review
}

Yüksek Doz Metoprolol Zehirlenme Vakası; Case Report ve Literatürün Gözden Geçirilmesi

\section{Metin Ocak ${ }^{1}$ MD, Halil Çetinkaya ${ }^{1}$ MD, Hüseyin Kesim $^{1}$ MD}

${ }^{1}$ Gazı State Hospital, Emergency Clinic Samsun, Turkey

\section{Corresponding Author: Dr. Metin Ocak. Gazı State Hospital, Emergency Clinic \\ Samsun, Turkey. \\ e-mail:mdmocak@gmail.com}

Received : 23.09.2019

Accepted :29.09.2021

Published: 08.10.2021

ORCID: 0000-0002-9978-0216

\section{Abstract}

$\beta$-Blockers are prescribed by physicians for many medical reasons (hypertension, long-term prophylaxis of angina pectoris, myocardial infarction, stable heart failure treatment, cardiac arrhythmias, etc.). Although cases of $\beta$-blocker poisoning have a low rate of $0.9 \%$ among all poisoning cases, they have a high mortality rate. Metoprolol, a type of $\beta$-blocker, is a selective $\beta 1$-adrenoceptor antagonist with sympathomimetic effect. This article aims to present a case who took high-dose metoprolol for suicidal purposes and to examine metoprolol poisoning and its treatment in the light of current literature.

\section{Öz}

$\beta$-blokerler hekimler tarafından bir çok tıbbi gerekçe ile reçete edilmektedirler (Hipertansiyon, anjina pektorisin uzun süreli profilaksisi, myokard infarktüsü, stabil kalp yetmezliği tedavisi, kardiyak aritmiler, v.b.). $\beta$-bloker zehirlenmeleri tüm zehirlenmeler içerisinde $\% 0.9$ gibi düşük bir orana sahip olsa da mortalite oranı yüksek seyretmektedirler. Bir $\beta$-bloker çeșidi olan metoprolol sempatomimetik etkisi olan selektif $\beta 1$-adrenoseptör antagonistidir. Bu makalede suisid amaçlı yüksek doz metoprolol alan bir olgunun sunumu ve metoprolol zehirlenmelerinin ve tedavisinin güncel literatür 1șığında incelenmesi amaçlanmıştır. 


\section{Introduction}

Beta-adreno receptor antagonists, more commonly known as $\beta$-blockers, are prescribed by physicians for many medical reasons (hypertension, long-term prophylaxis of angina pectoris, myocardial infarction, stable heart failure treatment, cardiac arrhythmias, etc.) (1). Although cases of $\beta$-blocker poisoning have a low rate of $0.9 \%$ among all poisoning cases, they have a high mortality rate (2). According to the data of the American Poison Control Center published in 2019, $\beta$ blocker poisoning is reported to be in the 7th place among 25 deadly substances (3). In $\beta$-blocker poisoning with high lipid solubility; serious central nervous system findings such as seizures, respiratory depression, and coma may be encountered (2). In $\beta$-blocker poisoning with high lipid solubility; serious central nervous system findings such as seizures, respiratory depression, and coma may be encountered. In addition, resistant bradycardia-hypotension and shock may occur due to cardiac involvement (2). Metoprolol, a type of $\beta$ blocker, is a selective $\beta 1$-adrenoceptor antagonist with sympathomimetic effect (4). In addition, it has been reported that metoprolol is the second most commonly prescribed $\beta$ blocker after bisoprolol worldwide (5). This article aims to present a case who took high-dose metoprolol for suicidal purposes and to discuss metoprolol poisonings in the light of current literature

\section{Case Report}

The patient, who had a previously known diagnosis of diabetes mellitus, coronary artery disease and schizophrenia, was found unconscious at home by his relatives. The patient was brought to the emergency room by the emergency medical call center (112) teams. In the physical examination findings of the patient; his general condition was poor, he was unconscious, his respiration was superficial, arterial blood pressure: 60/40 mmHg, heart rate: 46/min, and glasgow coma score: 5 . Elective endotracheal intubation was applied to the patient to ensure airway safety. Bolus IV fluid therapy, dopamine and nor-epinephrine infusion were administered for blood pressure regulation. In the first anamnesis taken from the relatives of the patient, it was learned that the patient did not have any problems and suddenly became ill. There was no evidence of poisoning in the first anamnesis. In the patient's examinations, the findings were as follows: ph:7.29, PO2:52 mmHg, PCO2:36.1 mmHg, HCO3:17.7 mmol/L, Wbc:11.9 10^9/L, Hgb:13.1 g/dL, plt:120 10^9/L, glucose:319 mg /dL, creatinine: $1.5 \mathrm{mg} / \mathrm{dL}$, Na:128 mmol/L, CRP: $20 \mathrm{mg} / \mathrm{L}$. First degree AV block and bradycardia were detected in the patient's electrocardiography. In the patient's abdominal tomography, a linear well-circumscribed image suggestive of multiple drug capsules was seen in the gastric lumen (Figure 1).

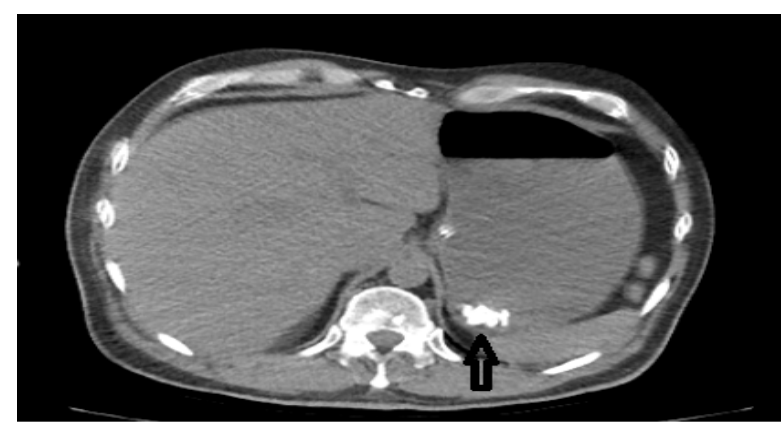

Figure 1. Drug particles visible in the stomach lumen on the patient's abdominal tomography

Thereupon, the relatives of the patients were informed that there might be drug intoxication and they were asked to look for the drug boxes at home. About 1 hour later, the patient's relative said that the patient may have taken about 40 of his own medicine, which contains $50 \mathrm{mg}$ of metoprolol. Thereupon, gastric lavage with nasogastric tube and $50 \mathrm{gr}$ activated charcoal were applied to the patient. It was observed that drug particles came from the lavage fluid. Since the arterial blood pressure values of the patient were $60 / 30 \mathrm{mmHg}$, the patient was administered $3 * 1 \mathrm{mg}$ of atropine. In addition, calcium gluconate $30 \mathrm{ml}$ slow push was applied to the patient. Since there was no response to atropine and calcium treatment, $2 * 5$ mg glucagon treatment was administered to the patient with an interval of 15 minutes. Since there was no adequate response to this treatment, the patient was started on $5 \mathrm{mg} /$ hour IV infusion therapy. The patient was admitted to the intensive care unit for continued treatment and follow-up. The patient, who did not respond to all supportive treatments in the intensive care unit, was requested to be referred to the upper center for further treatment.

However, the patient whose hemodynamics was unstable could not be referred. Despite all the interventions, the patient died approximately 36 hours after hospitalization.

\section{Discussion}

Blockade of $\beta$-receptors results in decreased production of intracellular cyclic adenosine monophosphate (cAMP). As a result, the multiple metabolic and cardiovascular effects of circulating catecholamines are reduced (6). The most important predictive factor in $\beta$-blocker toxicity is whether the drug has membrane stabilizing activity. It is known that metoprolol has low membrane stabilizing activity only at high doses (7). It is reported that the therapeutic plasma concentration range of metoprolol in the treatment of cardiovascular diseases is $0.035-0.50 \mathrm{mg} / \mathrm{L}$ (8). Metoprolol is metabolized by the liver and excreted by the kidneys. The half-life is 3-7 hours. It has moderate lipid solubility and blocks $\beta 1$ adrenergic receptors. It is reported that the threshold value is $400 \mathrm{mg}$ in adults and $5 \mathrm{mg} / \mathrm{kg}$ in children (9). Metoprolol overdose, depending on the dose taken in the clinic, may lead to symptoms such as bradycardia, hypotension, cardiogenic shock, hypoglycemia, hypothermia, seizure, altered consciousness, QT prolongation and QRS enlargement (10). In this case, the dose taken by the patient was not clear due to the unreliability of the anamnesis and the inability to measure the blood metoprolol level in our hospital. Our patient had signs of hypotension, cardiogenic shock, bradycardia, first-degree AV block, and altered consciousness.

Due to its lipophilic properties, the drug crosses the bloodbrain barrier in $\beta$-blocker poisoning and central nervous system effects may be observed. Therefore, rapid airway management is important in such patients (9). In literature, majority of the publications recommend gastric lavage and the administration of activated charcoal in $\beta$-blocker poisoning $(11,12)$. However, cases that died despite gastric lavage and administration of activated charcoal were also reported (13). Removal of drug particles by lavage after high-dose drug intake may have a positive effect on prognosis. However, in this case, it was thought that the lavage procedure limited its possible positive effect. In case of seizures in $\beta$-blocker poisoning, the first choice is benzodiazepines. If there is QTc prolongation, magnesium sulfate is given; if QRS widening is present, sodium bicarbonate is given in the treatment (9).

In the treatment of hypotension and shock, IV fluids and ketocalamine and/or high-dose insulin euglycemic treatments are recommended. The mechanism of action of high-dose insulin therapy in $\beta$-blocker poisoning is not clear. In the literature, it is unclear whether high-dose euglycemic insulin therapy or ketocalamine therapy is superior. However, case series in which high-dose insulin euglycemic therapy is more effective constitute the majority $(1,14,15)$. In another study, it was reported that the combined use of ketocalamine and high-dose insulin euglycemic therapy is more effective (16). Such patients may also benefit from the treatment of calcium salts (7). In this case, the patient was administered ketocalamine and 
calcium therapy, but no adequate response was obtained. The effect of IV glucagon therapy in patients with hypotensive and cardiogenic shock is also unclear when compared to other agents. Glucagon activates adenylate cyclase independently of beta-adrenergic agents and causes an increase in cAMP. increased cAMP: Increases the amount of intracellular calcium required for depolarization by increasing contractility. In a previous study, it was reported that high-dose glucagon treatment increased mean arterial pressure and mean heart rate (17). In another study, it was reported that glucagon therapy was not superior to high-dose insulin euglycemic therapy and lipid emulsion therapy (18). In previous studies on animals studies, it has been reported that IV glucagon treatment increases heart rate but does not have a positive effect on mean arterial pressure, cardiac output and mortality $(14,20)$. In this case, the patient was administered IV glucagon bolus and infusion therapy, but no response was obtained. There are limited publications in the literature supporting the efficacy of atropine therapy in bradycardia for $\beta$-blocker poisoning. In a previous case report, it was reported that $0.5 \mathrm{mg}$ of atropine treatment increased heart rate and mean arterial pressure in a 15-year-old female patient who received $500 \mathrm{mg}$ of atenolol (20). In a previous study on animal, it was reported that IV atropine was effective in correcting bradycardia due to propranolol overdose (21). The patient in this presentation was also administered IV atropine treatment, but no response was obtained.

There are many case reports and animal studies investigating the effectiveness of IV lipid emulsion therapy in the treatment of $\beta$-blocker poisoning. However, there is no clear evidence supporting the effectiveness of this treatment. In a previous study with 36 patients, 10 patients were given IV lipid emulsion therapy and it was found to be ineffective (22). However, in some case reports, it has been reported that IV lipid emulsion therapy increases heart rate and blood pressure $(11,12,23)$. An experimental study showed that high-dose insulin therapy was more effective than IV lipid emulsion therapy (24). More extensive studies are needed to investigate the efficacy of this treatment.

Since metoprolol is not a water-soluble drug, hemodialysis treatment has no efficacy on it (9). Veno-arterial extracorporeal membrane oxygenation (V-A ECMO) therapy also plays an active role in $\beta$-blocker poisoning in cardiogenic shock resistant to all pharmacotherapy. In a previous comparative observational study, V-A ECMO treatment was shown to be effective in eliminating hemodynamic instability (25).

There are case reports reporting that cardiac pacemaker application is also effective to eliminate hemodynamic instability in $\beta$-blocker poisoning cases (26).

As a result, treatment of $\beta$-blocker poisoning is complex and difficult for physicians. Despite all treatment efforts, mortality is high in such patients. If possible, these patients should be treated and followed up in fully equipped hospitals with toxicology centers. In treatment, catecholamines, vasopressors, fluid therapy, high-dose insulin euglycemic therapy and V-A ECMO applications have a mortality-lowering effect. However, the mortality-reducing effect of glucagon, lipid emulsion therapy, calcium and atropine is not clear (1)

\section{Conflict of Interest: None declared}

\section{References}
1. Rotella JA, Greene SL, Koutsogiannis Z, Graudins A, Hung Leang Y, Kuan K, et al. Treatment for beta- blocker poisoning: a systematic review. Clin Toxicol (Phila). 2020 Oct;58(10):943-983.
2. Karabıyık L, Kalın BS, Aydın EM, Nadastepe Ö. Intra- venous Lipid Emulsion Treatment for Propranolol in the Management of Multiple Drug Intoxication. Turk J In- tensive Care. 2019;17:221-5
3. Gummin DD, Mowry JB, Spyker DA, et al. 2018 Annual Report of the American Association of Poison Control

Centers' National Poison Data System (NPDS): 36th Annual Report. Clin Toxicol (Phila). 2019; 57:1-194.

4. Kriikku P, Pelkonen S, Kaukonen M, Ojanperä I. Propranolol and metoprolol: Two comparable drugs with very different post-mortem toxicological profiles. Forensic Sci Int. 2021 Aug 25; 327:110978.

5. 〈h〉/ttps://www.whocc.no/atc_ddd_index/>.

6. Unverir P, Topacoglu H, Bozkurt S, Kaynak F. Cardiovascular toxicity due to metoprolol poisoning in a patient with coronary artery disease. Br J Clin Pharmacol. 2007 Nov;64(5):694-7.

7. Carlin TM. Beta-blocker toxicity. In: Emergency Medicine: A Comprehensive Study Guide, 6th edn, eds Tintinalli JE, Kelen GD, Stapczynski JS. New York: McGraw-Hill 2004: 1105-8.

8. Schulz M, Schmoldt A, Andresen-Streichert H, IwersenBergmann S. Revisited: Therapeutic and toxic blood concentrations of more than 1100 drugs and other xenobiotics. Crit Care. 2020 May 6;24(1):195.

9. Bala P, Ali A, Rahman KA, Islam N, Khan MH. A Case of Massive Metoprolol Overdose Successfully Managed. Bangladesh Heart Journal. 2020; 35(1): 71-3

10. Kerns W II, Kline J, Ford MD. Betablocker and calcium channel blocker toxicity. Emerg Med Clin North Am. 1994; 12:365-90.

11. Barton CA, Johnson NB, Mah ND, Beauchamp G, Hendrickson R. Successful treatment of a massive metoprolol overdose using intravenous lipid emulsion and hyperinsulinemia/euglycemia therapy. Pharmacotherapy. 2015 May;35(5):e56-60.

12. Czerwonka E, Heim M. Lipid rescue therapy and hyperinsulinemia/ euglycemia for atenolol and zolpidem overdose. Crit Care Med. 2015;43 (12 (supplement 1):316.

13. Amundson DE, Brodine SK. A fatal case of propranolol poisoning. Drug Intell Clin Pharm. 1988 Oct;22(10):7812

14. Holger JS, Engebretsen KM, Obetz CL, Kleven TL, Harris CR. A comparison of vasopressin and glucagon in beta-blocker induced toxicity. Clin Toxicol (Phila). 2006;44(1):45-51.

15. Holger JS, Engebretsen KM, Fritzlar SJ, Patten LC, Harris CR, Flottemesch TJ. Insulin versus vasopressin and epinephrine to treat beta-blocker toxicity. Clin Toxicol (Phila). 2007 May;45(4):396-401.

16. Katzung KG, Leroy JM, Boley SP, Stellpflug SJ, Holger JS, Engebretsen KM. A randomized controlled study comparing high-dose insulin to vasopressors or combination therapy in a porcine model of refractory propranolol-induced cardiogenic shock. Clin Toxicol (Phila). 2019 Nov;57(11):1073-79.

17. Catlin J, Wilson M, Traylor B. Weight-based dosing for intravenous glucagon bolus is associated with chronotropic response in beta-blocker toxicity. J Med Toxicol. 2018;14(1):53.

18. Gerwin H, Behrman A, Goetz R, Otten E, Foertsch M, Hillebrand K, et al. Predictors of response to insulin, glucagon, and lipid emulsion in antihypertensive overdose. Crit Care Med. 2015;43(1):32.

19. Sato S, Tsuji MH, Okubo N, Nishimoto C, Naito H. Combined use of glucagon and milrinone may not be preferable for severe propranolol poisoning in the canine model. J Toxicol Clin Toxicol. 1995;33(4):337-42.

20. Abbasi IA, Sorsby S. Prolonged toxicity from atenolol overdose in an adolescent. Clin Pharm. 1986 Oct;5(10):836-7.

21. Kandil A, Abd-Ellatif M, Abd-Elwahed K. Aversion of the cardiac toxicity of propranolol by atropine. J Drug Res. 1979;11(1-2):17-26.

22. Mithani S, Dong K, Wilmott A, Podmoroff H, Lalani N, Rosychuk RJ, et al. A cohort study of unstable overdose patients treated with intravenous lipid emulsion therapy. CJEM. 2017 Jul;19(4):256-264

23. Markota A, Hajdinjak E, Rupnik B, Sınkovič A. Treatment of near-fatal beta blocker and calcium channel blocker intoxication with hyperinsulinemic euglycemia, intravenous lipid emulsions and high doses of norepinephrine. Signa Vitae. 2015;10(1):144-150.

24. Harvey M, Cave G, Lahner D, Desmet J, Prince G, Hopgood G. Insulin versus Lipid Emulsion in a Rabbit 
Model of Severe Propranolol Toxicity: A Pilot Study.

Crit Care Res Pract. 2011; 2011:361737.

25. Masson R, Colas V, Parienti JJ, Lehoux P, Massetti M,

Charbonneau $\mathrm{P}$, et al. A comparison of survival with and without extracorporeal life support treatment for severe poisoning due to drug intoxication. Resuscitation. 2012 Nov;83(11):1413-7.

26. Tötterman KJ, Turto H, Pellinen T. Overdrive pacing as treatment of sotalol-induced ventricular tachyarrhythmias (torsade de pointes). Acta Med Scand Suppl. 1982; 668:28-33. 